\title{
ANALISIS PENGARUH CAR, FDR, NPF, DAN PERTUMBUHAN DPK TERHADAP PROFITABILITAS PADA INDUSTRI BANK PEMBIAYAAN RAKYAT SYARIAH DI INDONESIA TAHUN 2011-2015
}

\author{
Retno Wulandari \\ Mahasiswa Program Studi Ekonomi Islam-Fakultas Ekonomi dan Bisnis-Universitas Airlangga \\ Email: retno.wulandari-12@feb.unair.ac.id
}

\author{
Atina Shofawati \\ Departemen Ekonomi Syariah-Fakultas Ekonomi dan Bisnis-Universitas Airlangga \\ Email: atina-o@feb.unair.ac.id
}

\begin{abstract}
:
This research aims to analyze the influence of Capital Adequacy Ratio (CAR), Financing to Deposit Ratio (FDR), Non Performing Financing (NPF), and Third Party Fund Growth (DPK growth) to Return On Assets (ROA) of Islamic Rural Bank in Indonesia. All data that uses in this research contained from Sharia Banking Statistic (SPS) Bank Indonesia. This research used the quantitative approach method. The data analysis method used in this research is multiple linear regression analysis. Based on the results of this research showed that simultaneously CAR, FDR, NPF, and DPK growth had significant effect to ROA with significant value 0,000. Partially, CAR had not significant effect to ROA, but FDR, NPF, and DPK growth partially had significant effect to ROA. The ability of CAR, FDR, NPF, and DPK growth in explaining ROA ratio of $58 \%$, and the remaining $42 \%$ was explained by other variables outside the model used in this research.
\end{abstract}

Keywords: CAR, FDR, NPF, DPK growth, ROA

\section{PENDAHULUAN}

\section{Latar Belakang}

Perbankan merupakan salah satu lembaga kevangan yang berperan sebagai lembaga intermediasi, dimana perbankan harus memiliki kinerja yang baik demi mendapatkan kepercayaan dari para nasabah. Sukarno dan Syaichu (2006) menjelaskan perbankan sebagai badan usaha yang bergerak di bidang kevangan atau finansial sangat membutuhkan kepercayaan dari para nasabah guna mendukung dan memperlancar kegiatan yang dilakukan perbankan.

Bank syariah di Indonesia pertama kali didirikan pada tahun 1992 adalah Bank Muamalat Indonesia (BMI). Ismail (2011:31) menjelaskan sejak adanya krisis moneter yang melanda Indonesia pada 1997 dan 1998, para bankir melihat bahwa Bank Muamalat Indonesia (BMI) tidak terlalu terkena dampak krisis moneter. Para bankir berpikir bahwa BMl, satu-satunya bank syariah di Indonesia, tahan terhadap krisis moneter.

Bank Syariah di Indonesia terbagi menjadi tiga jenis, yaitu Bank Umum Syariah, Unit Usaha Syariah, dan Bank Pembiayaan Rakyat Syariah. Bank Pembiayaan Rakyat Syariah (BPRS) adalah perbankan yang melaksanakan kegiatan usaha berdasarkan prinsip syariah dimana dalam kegiatannya tidak memberikan jasa dalam lalu lintas pembayaran. Intermediasi yang dilakukan berupa penghimpunan dana maupun penyaluran dana dari pihak yang memiliki 
Wulandari, et al/Jurnal Ekonomi Syariah Teori dan Terapan Vol. 4 No. 9 September 2017: 741-756; ANALISIS PENGARUH CAR, FDR, NPF, DAN PERTUMBUHAN DPK TERHADAP PROFITABILITAS PADA INDUSTRI BANK PEMBIAYAAN RAKYAT SYARIAH DI INDONESIA TAHUN 2011-2015

kelebihan dana kepada pihak yang membutuhkan dana. Pada dasarnya, BPRS sebagai lembaga keuangan syariah dapat memberikan jasa-jasa keuangan yang serupa dengan bank-bank umum syariah (Sudarsono, 2007:85).

BPRS merupakan salah satu lembaga keuangan yang profit oriented. Pada kondisi ini BPRS lebih mengutamakan perolehan tingkat keuntungan dalam kegiatan operasinya. Perhitungan rasio untuk menilai posisi kinerja suatu bank, akan memberikan gambaran yang jelas tentang baik atau tidaknya operasional suatu bank, yang dilihat dari posisi keuangannya dalam neraca dan labarugi (Faisol, 2007).

Rasio profitabilitas merupakan salah satu rasio yang digunakan untuk menentukan tingkat keuntungan suatu bank. Rasio ini juga biasa disebut Return On Assets (ROA). Dendawijaya (2009:118) menyatakan bahwa ROA digunakan untuk mengukur kemampuan manajemen bank dalam memperoleh keuntungan (laba) secara keseluruhan. Semakin besar ROA yang diperoleh bank, maka semakin besar tingkat keuntungan yang dicapai oleh bank.

ROA dapat dipengaruhi oleh beberapa kinerja perbankan, diantaranya adalah Capital Adequacy Ratio, Financing to Deposit Ratio, Non Performing Financing, dan pertumbuhan dana pihak ketiga. Capital Adequacy Ratio (CAR) merupakan indikator terhadap kemampuan bank untuk menutupi penurunan aktivanya sebagai akibat dari kerugian-kerugian bank yang disebabkan oleh aktiva yang berisiko (Dendawijaya, 2009:121). Semakin besar CAR menunjukkan bahwa manajemen bank dalam menutupi kerugian dan risiko semakin baik. Hal ini dapat mempengaruhi keuntungan yang diperoleh bank akibat pengelolaan modal yang optimal.

Financing to Deposit Ratio (FDR) merupakan rasio yang digunakan oleh bank untuk mengukur tingkat likuiditas yang bertujuan mengetahui kemampuan bank dalam memenuhi permintaan pembiayaan dengan menggunakan total aset yang dimiliki oleh bank. Sholihin (2010:227) menjelaskan bahwa FDR merupakan persentase perbandingan antara pembiayaan yang diberikan dan dana pihak ketiga yang dihimpun oleh bank syariah. Meningkatnya FDR menunjukkan penyaluran dana yang dilakukan oleh bank dalam bentuk pembiayaan semakin meningkat, sehingga dapat berpengaruh pada keuntungan yang diperoleh bank.

Fungsi bank syariah sebagai lembaga intermediary dalam kaitannya dengan penyaluran dana masyarakat atau fasilitas pembiayaan berdasarkan prinsip syariah tersebut, bank syariah menanggung risiko kredit atau risiko pembiayaan (Wangsawidjaja Z, 2012:89). Risiko pembiayaan ini disebut Non Performing Financing (NPF). NPF merupakan persentase pembiayaan terjadi akibat keterlambatan dalam pembayaran cicilan (Sholihin, 2010:557). 
Wulandari, et al/Jurnal Ekonomi Syariah Teori dan Terapan Vol. 4 No. 9 September 2017: 741-756; ANALISIS PENGARUH CAR, FDR, NPF, DAN PERTUMBUHAN DPK TERHADAP PROFITABILITAS PADA INDUSTRI BANK PEMBIAYAAN RAKYAT SYARIAH DI INDONESIA TAHUN 2011-2015

Semakin kecil NPF yang diperoleh bank menunjukkan semakin baik manajemen bank dalam menangani risiko pembiayaan sehingga hal ini dapat meningkatkan laba bank.

Dendawijaya (2009:49) menyatakan bahwa bank harus selalu berada di tengah masyarakat agar arus vang dari masyarakat yang kelebihan dana dapat ditampung dan disalurkan kembali kepada masyarakat. Dana yang bersumber dari masyarakat atau dana pihak ketiga (DPK) merupakan sumber dana terpenting bagi kegiatan operasional suatu bank dan merupakan ukuran keberhasilan bank jika mampu membiayai operasinya dari sumber dana ini. Semakin banyak dana yang diperoleh bank maka akan berpengaruh terhadap kinerja bank yang semakin baik sehingga keuntungan yang diperoleh bank juga meningkat.

Berdasarkan latar belakang masalah tersebut menunjukkan adanya hubungan CAR, FDR, NPF, dan pertumbuhan DPK terhadap ROA. Adanya hubungan tersebut menarik peneliti untuk melakukan penelitian yang berjudul "Analisis Pengaruh CAR, FDR, NPF. Dan Pertumbuhan DPK terhadap Profitabilitas pada Industri Bank Pembiayaan Rakyat Syariah di Indonesia Tahun 2011-2015."

\section{Rumusan Masalah}

1. Apakah Capital Adequacy Ratio (CAR), Financing to Deposit Ratio (FDR), Non Performing Financing (NPF), dan pertumbuhan Dana Pihak Ketiga (DPK) mempunyai pengaruh signifikan secara simultan terhadap Return On Assets (ROA) pada BPRS di Indonesia Tahun 2011-2015?

2. Apakah Capital Adequacy Ratio $(\mathrm{CAR})$, Financing to Deposit Ratio (FDR), Non Performing Financing (NPF), dan pertumbuhan Dana Pihak Ketiga (DPK) mempunyai pengaruh signifikan secara parsial terhadap Return On Assets (ROA) pada BPRS di Indonesia Tahun 2011-2015?

\section{Tujuan Penelitian}

1. Mengetahui pengaruh signifikan Capital Adequacy Ratio (CAR), Financing to Deposit Ratio (FDR), Non Performing Financing (NPF), dan pertumbuhan Dana Pihak Ketiga (DPK) secara simultan terhadap Return On Assets (ROA) pada BPRS di Indonesia Tahun 201 1-2015.

2. Mengetahui pengaruh signifikan Capital Adequacy Ratio (CAR), Financing to Deposit Ratio (FDR), Non Performing Financing (NPF), dan pertumbuhan Dana Pihak Ketiga (DPK) secara parsial terhadap Return On Assets (ROA) pada BPRS di Indonesia Tahun 2011 1-2015.

\section{LANDASAN TEORI \\ PENGEMBANGAN HIPOTESIS}

DAN

Bank Pembiayaan Rakyat Syariah (BPRS) adalah perbankan yang melaksanakan kegiatan usaha berdasarkan prinsip syariah dimana dalam kegiatannya tidak memberikan jasa dalam lalu lintas pembayaran. Intermediasi yang dilakukan berupa penghimpunan dana maupun penyaluran 
Wulandari, et al/Jurnal Ekonomi Syariah Teori dan Terapan Vol. 4 No. 9 September 2017: 741-756; ANALISIS PENGARUH CAR, FDR, NPF, DAN PERTUMBUHAN DPK TERHADAP PROFITABILITAS PADA INDUSTRI BANK PEMBIAYAAN RAKYAT SYARIAH DI INDONESIA TAHUN 2011-2015

dana dari pihak yang memiliki kelebihan dana kepada pihak yang membutuhkan dana. Pada dasarnya, BPRS sebagai lembaga keuangan syariah dapat memberikan jasa-jasa keuangan yang serupa dengan bank-bank umum syariah (Sudarsono, 2007:85). Tujuan didirikannya BPRS adalah memberikan pembiayaan kepada masyarakat khususnya masyarakat menengah kebawah yang membutuhkan biaya demi mengembangkan usahanya.

Kinerja perusahaan juga dapat menjadi tolak ukur atas pencapaian yang telah berhasil dilaksanakan oleh perusahaan. Prasetyoningrum (2010) menyatakan bahwa pada umumnya banyak peneliti yang melakukan penilaian kinerja suatu lembaga keuangan syari'ah dengan menggunakan rasio keuangan yang dikatagorikan seperti likuiditas, solvabilitas, profitabilitas dan efisiensi.

Capital Adequacy Ratio (CAR) adalah rasio yang sangat berhubungan dengan permodalan dalam perbankan. Dendawijaya (2009:121) menjelaskan CAR adalah rasio yang memperlihatkan seberapa jauh seluruh aktiva bank yang mengandung risiko ikut dibiayai dari dana modal sendiri bank. Dengan kata lain, CAR adalah rasio kinerja bank untuk mengukur kecukupan modal yang dimiliki bank untuk menunjang aktiva yang mengandung risiko. Besarnya modal yang dimiliki oleh bank sangat berpengaruh dalam kemampuan suatu bank dalam menjalankan kegiatan usahanya secara efisien.
Financing to Deposit Ratio (FDR) adalah perbandingan pembiayaan yang diberikan oleh bank dengan dana pihak ketiga yang berhasil dikerahkan oleh bank (Sholihin, 2010:227). Sedangkan menurut Hartono (2007:10) Financing to Deposit Ratio adalah karakteristik pada perbankan syariah dalam memaksimalkan pendapatan, yang membuat ekspansi pembiayaan menjadi sesuatu yang tidak dapat dihindari oleh perbankan syariah seiring dengan meningkatnya jumlah Dana Pihak Ketiga (DPK), peningkatan DPK tanpa diimbangi peningkatan pembiayaan akan mengurangi bagi hasil yang diterima nasabah.

Wangsawidjaja Z (2012:90) menjelaskan pembiayaan bermasalah atau Non Performing Financing adalah pembiayaan yang kualitasnya berada dalam golongan kurang lancar (golongan III), diragukan (golongan IV), dan macet (golongan V). NPF dari segi produktivitasnya berkaitan dengan kemampuan menghasilkan pendapatan bagi bank sudah berkurang atau menurun dan kemungkinan tidak ada lagi. Hal ini terjadi akibat persentase pembiayaan yang tidak perform, mengalami keterlambatan dalam pembayaran cicilan (Sholihin, 2010:557). Semakin besar nilai NPF maka semakin buruk kinerja bank tersebut.

Kuncoro (2002:155) menjelaskan bahwa DPK merupakan dana yang berasal dari masyarakat, baik perorangan maupun badan usaha yang diperoleh bank dengan menggunakan berbagai instrumen produk simpanan yang dimiliki 
Wulandari, et al/Jurnal Ekonomi Syariah Teori dan Terapan Vol. 4 No. 9 September 2017: 741-756; ANALISIS PENGARUH CAR, FDR, NPF, DAN PERTUMBUHAN DPK TERHADAP PROFITABILITAS PADA INDUSTRI BANK PEMBIAYAAN RAKYAT SYARIAH DI INDONESIA TAHUN 2011-2015

oleh bank. Pertumbuhan dana pihak ketiga merupakan salah satu faktor internal yang dapat berpengaruh terhadap peningkatan profitabilitas. Hal ini dikarenakan dana pihak ketiga merupakan komponen dari pasiva yang likuid, dimana dana secara cepat dapat diputar kembali sehingga dapat meningkatkan profitabilitas (Sukmawati dan Purbawangsa, 2016).

Kasmir (2008:196) menjelaskan bahwa dalam mengukur tingkat keuntungan, perusahaan menggunakan rasio keuntungan atau rasio profitabilitas yang juga disebut rasio rentabilitas. Selain itu, dengan kondisi perusahaan yang baik itu menunjukkan bahwa semakin baik manajemen dalam mengelola usaha. Salah satu komponen rasio profitabilitas adalah Return On Assets (ROA). ROA adalah laba setelah pajak dengan total aktiva, rasio ini digunakan untuk mengukur tingkat produktivitas aset (Martono dan Harjito, 2008:59).

\section{Hubungan Antar Variabel}

1. Pengaruh CAR Terhadap ROA

Arifin (2009:162) menyatakan CAR merupakan rasio yang digunakan untuk mengetahui tingkat kecukupan modal. Semakin kecil nilai CAR maka akan menyebabkan penurunan modal yang dimiliki untuk menutupi risiko kerugian yang terjadi. Sebaliknya, semakin tinggi nilai CAR maka akan dapat meningkatkan pendapatan bank, sehingga CAR berpengaruh terhadap meningkatnya profitabilitas. Azwir (2006) dalam penelitiannya menyatakan bahwa
CAR berpengaruh signifikan terhadap ROA.

2. Pengaruh FDR Terhadap ROA

FDR adalah rasio antara dana yang ditempatkan pada pembiayaan dibandingkan dengan dana yang dihimpun dari masyarakat atau dana pihak ketiga. Menurut Dendawijaya (2009:116) rasio ini juga digunakan untuk mengetahui seberapa jauh pemberian pembiayaan kepada nasabah dapat mengimbangi kewajiban bank untuk segera memenuhi permintaan deposan yang ingin menarik kembali vangnya yang telah digunakan oleh bank untuk pemberian pinjaman. Apabila FDR meningkat maka laba yang diperoleh bank juga naik dengan asumsi bahwa bank mampu menyalurkan pembiayaan secara optimal. Riyadi dan Yulianto (2014) dalam penelitiannya menyatakan bahwa FDR berpengaruh signifikan terhadap ROA.

\section{Pengaruh NPF Terhadap ROA}

Pembiayaan bermasalah atau NPF disebabkan oleh kegagalan pihak debitur memenuhi kewajibannya untuk membayar angsuran pinjaman yang sebelumnya telah disepakati dalam perjanjian kedua belah pihak (Dendawijaya, 2009:82). NPF dapat mengakibatkan hilangnya kesempatan untuk memperoleh pendapatan dari pembiayaan yang diberikan sehingga mempengaruhi perolehan laba dan berpengaruh buruk pada ROA, dengan demikian semakin besar NPF akan mengakibatkan menurunnya ROA. 
Wulandari, et al/Jurnal Ekonomi Syariah Teori dan Terapan Vol. 4 No. 9 September 2017: 741-756; ANALISIS PENGARUH CAR, FDR, NPF, DAN PERTUMBUHAN DPK TERHADAP PROFITABILITAS PADA INDUSTRI BANK PEMBIAYAAN RAKYAT SYARIAH DI INDONESIA TAHUN 2011-2015

Penelitian yang dilakukan oleh Anastasia dan Septiarini (2015) menunjukkan bahwa NPF berpengaruh signifikan terhadap ROA.

4. Pengaruh pertumbuhan DPK Terhadap $\mathrm{ROA}$

Dana pihak ketiga (DPK) merupakan salah satu sumber dana terbesar bagi bank yang diperoleh dari masyarakat. Bank memanfaatkan dana dari pihak ketiga ini untuk dialokasikan pada usaha bank syariah yang dapat menghasilkan pendapatan bagi bank, salah satunya yaitu dalam bentuk pembiayaan. Peningkatan dana pihak ketiga dapat menjadikan bank syariah mempunyai pelvang serta kesempatan yang lebih besar untuk memperoleh pendapatan yang lebih tinggi. Nirwana dan Septiarini (2015) menyatakan bahwa penghimpunan dana pihak ketiga yang semakin mengalami peningkatan, mengindikasikan semakin besarnya perhatian dan kesadaran masyarakat akan keberadaan lembaga keuangan (bank) yang sangat menguntungkan bagi mereka atas bagi hasil yang mereka peroleh. Semakin tinggi DPK yang diterima oleh bank syariah mempengaruhi besarnya pembiayaan yang disalurkan oleh bank kepada masyarakat. Dengan meningkatnya pembiayaan dapat mempengaruhi peningkatan laba bank syariah. Irianti (2013) dalam penelitiannya menyatakan DPK berpengaruh signifikan terhadap ROA.

\section{Hipotesis}

Hipotesis dalam penelitian ini dapat dirumuskan sebagai berikut:

$\mathrm{H}_{1}=$ Capital Adequacy Ratio, Financing to Deposit Ratio, Non Performing Financing, dan Pertumbuhan Dana Pihak Ketiga secara simultan berpengaruh signifikan terhadap Return On Assets pada BPRS di Indonesia periode 2011-2015.

$\mathrm{H}_{2}=$ Capital Adequacy Ratio secara parsial berpengaruh signifikan terhadap Return On Assets pada BPRS di Indonesia periode 2011-2015.

$\mathrm{H}_{3}=$ Financing to Deposit Ratio secara parsial berpengaruh signifikan terhadap Return On Assets pada BPRS di Indonesia periode 2011-2015.

$\mathrm{H}_{4}=$ Non Performing Financing secara parsial berpengaruh signifikan terhadap Return On Assets pada BPRS di Indonesia periode 2011-2015.

$\mathrm{H}_{5}=$ Pertumbuhan Dana Pihak Ketiga secara parsial berpengaruh signifikan terhadap Return On Assets pada BPRS di Indonesia periode 2011-2015.

\section{Model Analisis}

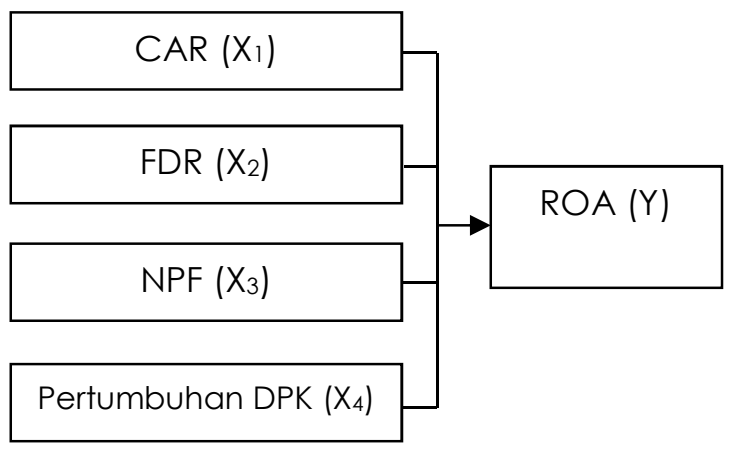

Sumber: Penulis.

Gambar 1.

Model Analisis Hubungan secara Simultan 
Wulandari, et al/Jurnal Ekonomi Syariah Teori dan Terapan Vol. 4 No. 9 September 2017: 741-756; ANALISIS PENGARUH CAR, FDR, NPF, DAN PERTUMBUHAN DPK TERHADAP PROFITABILITAS PADA INDUSTRI BANK PEMBIAYAAN RAKYAT SYARIAH DI INDONESIA TAHUN 2011-2015

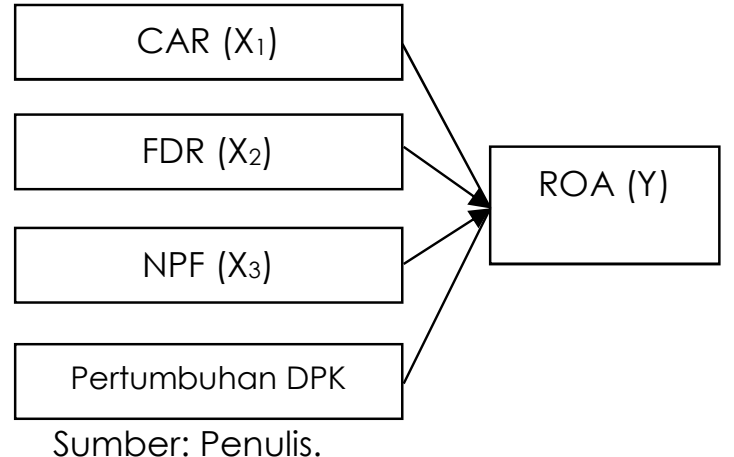

Gambar 2.

Model Analisis Hubungan secara Parsial

Persamaan yang digunakan dalam penelitian ini adalah sebagai berikut:

Keterangan:

$Y=a+\beta_{1} X_{1}+\beta_{2} X_{2}+\beta_{3} X_{3}+\beta_{4} X_{4}+e_{1}$

$Y=$ Return On Assets (ROA)

$a=$ Konstanta (intercept)

$\beta=$ Koefisien Regresi

$\mathrm{X}_{1}=$ Capital Adequacy Ratio (CAR)

$\mathrm{X}_{2}=$ Financing to Deposit Ratio (FDR)

$X_{3}=$ Non Performing Financing (NPF)

$\mathrm{X}_{4}=$ Pertumbuhan Dana Pihak Ketiga (DPK)

\section{METODE PENELITIAN}

\section{Pendekatan Penelitian}

Pendekatan penelitian yang digunakan dalam penelitian ini adalah pendekatan kuantitatif. Hermawan mengatakan bahwa penelitian kuantitatif adalah suatu pendekatan penelitan yang bersifat obyektif, dimana mencakup pengumpulan dan analisis data kuantitatif serta menggunakan metode pengujian statistik dalam pengolahan datanya.

\section{Identifikasi Variabel}

Penelitian ini menggunakan dua jenis variabel, yaitu variabel independen dan dependen. Variabel independen dalam penelitian ini adalah Capital Adequacy Ratio (CAR), Financing to Deposit Ratio (FDR), Non Performing Financing (NPF), dan Pertumbuhan Dana Pihak Ketiga (DPK), sedangkan variabel dependen dalam penelitian ini adalah variabel yang bersifat terikat, dimana variabel ini kondisinya dipengaruhi oleh variabel independen. Variabel dependen dalam penelitian ini adalah Return On Assets (ROA).

\section{Definisi Operasional}

Definisi operasional dari masing-masing variabel yang digunakan dalam penelitian ini adalah sebagai berikut:

1. Capital Adequacy Ratio (CAR)

Menurut Dendawijaya (2009:121) berdasarkan ketentuan yang ditetapkan oleh Bank Indonesia dalam rangka tata cara penilaian tingkat kesehatan bank, terdapat ketentuan bahwa modal bank terdiri atas modal inti dan modal pelengkap. CAR merupakan rasio yang dihitung berdasarkan jumlah modal bank dengan total ATMR, sehingga CAR dapat dirumuskan sebegai berikut:

$C A R=\frac{\text { Modal Bank }}{\text { ATMR }} x 100 \%$

2. Financing to Deposit Ratio (FDR)

FDR merupakan rasio yang menunjukkan perbandingan antara pembiayaan yang diberikan dengan dana yang dihimpun dari masyarakat atau dana pihak ketiga. Sehingga, FDR dapat dirumuskan sebagai berikut:

$F D R=\frac{\text { Pembiayaan yang Diberikan }}{\text { Total Dana Pihak Ketiga }} \times 100 \%$

3. Non Performing Financing (NPF)

NPF merupakan salah satu rasio antara pembiayaan yang bermasalah dengan total pembiayaan yang 
Wulandari, et al/Jurnal Ekonomi Syariah Teori dan Terapan Vol. 4 No. 9 September 2017: 741-756; ANALISIS PENGARUH CAR, FDR, NPF, DAN PERTUMBUHAN DPK TERHADAP PROFITABILITAS PADA INDUSTRI BANK PEMBIAYAAN RAKYAT SYARIAH DI INDONESIA TAHUN 2011-2015

diberikan oleh perbankan syariah. Berdasarkan Surat Edaran Bank Indonesia Nomor 9/29/DPbs tanggal 7 Desember 2007, NPF dapat dihitung dengan menggunakan rumus sebagai berikut:

$N P F=\frac{\text { Pembiayaan Bermasalah }}{\text { Jumlah Pembiayaan }} \times 100 \%$

4. Pertumbuhan Dana Pihak Ketiga (DPK)

Pertumbuhan dana pihak ketiga dapat diketahui dengan menghitung selisih jumlah DPK periode saat ini dengan periode sebelumnya dibandingkan dengan jumlah DPK periode sebelumnya, sehingga DPK dapat diukur dengan rumus berikut:

Pertumbuhan DPK $=\frac{\operatorname{DPK}(\mathrm{t})-\mathrm{DPK}(\mathrm{t}-1)}{\operatorname{DPK}(\mathrm{t}-1)} \times 100 \%$

5. Return On Assets (ROA)

ROA menunjukkan besarnya nilai keuntungan atau laba yang didapatkan oleh bank. Semakin besar laba yang diperoleh maka semakin baik kondisi perusahaan tersebut. ROA dapat dirumuskan sebagai berikut (Dendawijaya, 2009:118):

$R O A=\frac{\text { Laba Bersih }}{\text { Total Aktiva }} \times 100 \%$

\section{Jenis dan Sumber Data}

Data yang digunakan dalam penelitian ini adalah data sekunder. Data sekunder yang terdapat dalam penelitian ini yaitu data CAR, FDR, NPF, pertumbuhan DPK, dan ROA yang terdapat dalam laporan keuangan Bank Pembiayaan Rakyat Syariah dalam Statistik Perbankan Syariah yang diterbitkan oleh Bank Indonesia.

Laporan kevangan yang diterbitkan oleh Bank Indonesia dapat diperoleh melalui situs resmi milik Bank Indonesia yaitu www.bi.go.id. Data yang digunakan merupakan data time series bulanan dengan periode penelitian Januari 2011 sampai dengan Juni 2015.

\section{Populasi dan Sampel}

Populasi yang digunakan dalam penelitian ini adalah industri Bank Pembiayaan Rakyat Syariah (BPRS) di Indonesia yang terdaftar dalam Statistik Perbankan Syariah dengan menggunakan laporan keuangan publikasi periode 2011 sampai dengan Juni 2015.

Teknik yang digunakan dalam menentukan sampel dalam penelitian ini adalah teknik sampel jenuh. Anshori dan Iswati (2009:106) menjelaskan bahwa sampel jenuh adalah teknik penentuan sampel bila semua anggota populasi digunakan sebagai sampel. Data sampel yang digunakan dalam penelitian ini adalah industri BPRS di Indonesia periode Januari 2011 sampai dengan Juni 2015. Sampel dalam penelitian ini adalah sebanyak 54 periode penelitian.

\section{Teknik Analisis}

Penelitian ini menggunakan teknik analisis regresi linier berganda dengan menggunakan program SPSS 16 untuk melakukan pengujian datanya. Pengujian data menggunakan uji asumsi klasik, yaitu berupa uji normalitas, uji multikolinieritas, uji heteroskedastisitas, dan uji autokorelasi. Setelah itu, dilakukan pengujian koefisien determinasi $\left(R^{2}\right)$ dan uji hipotesis. Uji hipotesis meliputi uji $\mathrm{F}$ yang digunakan untuk mengetahui pengaruh variabel 
Wulandari, et al/Jurnal Ekonomi Syariah Teori dan Terapan Vol. 4 No. 9 September 2017: 741-756; ANALISIS PENGARUH CAR, FDR, NPF, DAN PERTUMBUHAN DPK TERHADAP PROFITABILITAS PADA INDUSTRI BANK PEMBIAYAAN RAKYAT SYARIAH DI INDONESIA TAHUN 2011-2015

independen terhadap variabel dependen secara simultan, dan uji † dilakukan untuk mengetahui pengaruh variabel independen terhadap variabel dependen secara parsial.

\section{IV.HASIL DAN PEMBAHASAN}

\section{Deskripsi Hasil Penelitian}

\section{Deskripsi CAR}

Nilai maksimum yang dicapai oleh CAR terjadi pada periode awal yaitu Januari 2011 dengan nilai sebesar 30,12\%, sedangkan nilai minimum yang diperoleh sebesar $21,37 \%$ yang terjadi pada periode Mei 2015 hingga Juni 2015. Rata-rata variabel CAR selama periode penelitian sebesar $24,04 \%$. Hal ini menunjukkan ratarata CAR dengan nilai $24,04 \%$ lebih besar dari persentase Aktiva Tertimbang Menurut Resiko (ATMR) dimana penyediaan modal minimum bank diukur dari persentase tertentu terhadap ATMR sebesar $8 \%$.

\section{Deskripsi FDR}

Nilai maksimum yang dicapai oleh FDR terjadi pada periode Agustus 2011 dengan nilai sebesar $139,58 \%$, sedangkan nilai minimum yang diperoleh sebesar $119,46 \%$ yang terjadi pada periode Februari 2013. Rata-rata variabel FDR selama periode penelitian sebesar $127,63 \%$.

\section{Deskripsi NPF}

Nilai maksimum yang dicapai oleh NPF terjadi pada periode Maret 2015 dengan nilai sebesar 10,36\%, sedangkan nilai minimum yang diperoleh sebesar 6,15\% yang terjadi pada periode Desember
2012. Rata-rata variabel NPF selama periode penelitian sebesar $7,54 \%$.

4. Deskripsi Pertumbuhan DPK

Nilai maksimum yang dicapai oleh pertumbuhan DPK terjadi pada periode Januari 2012 dengan nilai sebesar 4,61\%, sedangkan nilai minimum yang diperoleh sebesar $-2,25 \%$ yang terjadi pada periode Juni 2015. Rata-rata variabel pertumbuhan DPK selama periode penelitian sebesar $1,76 \%$.

5. Deskripsi ROA

Nilai maksimum yang dicapai oleh ROA terjadi pada periode April 2013 dengan nilai sebesar $3,14 \%$, sedangkan nilai minimum yang diperoleh sebesar 2,07\% yang terjadi pada periode Maret 2015. Rata-rata variabel ROA selama periode penelitian sebesar $2,65 \%$.

\section{Pengujian Asumsi Klasik}

1. Uji Normalitas

Uji normalitas digunakan untuk menguji apakah dalam regresi variabel pengganggu atau residualnya memiliki distribusi normal. Uji normalitas dapat dilakukan dengan menggunakan dua cara, yaitu menganalisis gambar Normal P-P Plot dan melakukan uji statistik.

Analisis gambar Normal P-P Plot dilakukan dengan melihat apakah titik-titik yang terdapat dalam gambar mengikuti sumbu diagonalnya. Apabila titik-titik tersebut mengikuti sumbu diagonalnya, maka data berdistribusi normal. Hasil pengujian Normal P-P Plot dapat dilihat pada Gambar 3 berikut. 
Wulandari, et al/Jurnal Ekonomi Syariah Teori dan Terapan Vol. 4 No. 9 September 2017: 741-756; ANALISIS PENGARUH CAR, FDR, NPF, DAN PERTUMBUHAN DPK TERHADAP PROFITABILITAS PADA INDUSTRI BANK PEMBIAYAAN

Normal P-P Plot of Regression Standardized Residual

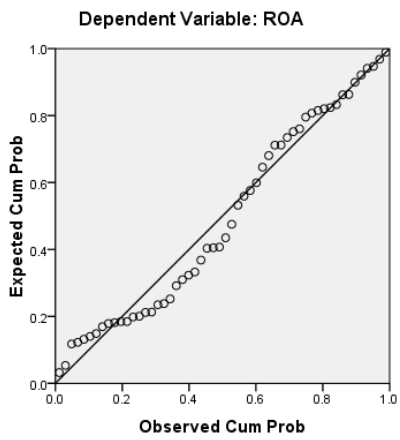

Sumber: Hasil Uji SPSS 16

Gambar 3

Hasil Uji Normal P-P Plot

Berdasarkan Gambar 3 terlihat bahwa titik-titik menyebar mengikuti sumbu diagonalnya, sehingga model regresi lolos uji normalitas.

Uji statistik ini dilakukan dengan menggunakan besaran KolmogorovSmirnov. Apabila signifikansi dari masingmasing variabel lebih dari 0,05 maka data berdistribusi normal (Sujarweni, 2014:55). Hasil pengujian normalitas dengan uji Kolmogorov-Smirnov dapat dilihat pada Tabel 1 berikut.

Tabel 1

Hasil Uji Normalitas Kolmogorov-Smirnov

\begin{tabular}{|c|c|c|}
\hline $\begin{array}{c}\text { Asymp. Sig. } \\
\text { (2-tailed) }\end{array}$ & $\alpha$ & Keterangan \\
\hline 0,555 & 0,05 & $\begin{array}{c}\text { Nilai signifikansi uji } \\
\text { normalitas lebih } \\
\text { besar dari } \alpha \\
(0,555>0,05)\end{array}$ \\
\hline
\end{tabular}

Sumber: Hasil Uji SPSS 16

Berdasarkan Tabel 1 dapat disimpulkan bahwa data yang digunakan berdistribusi normal.

2. Uji Multikolinieritas

Nilai yang dipakai untuk menunjukkan adanya multikolinieritas adalah nilai tolerance $\leq 0.10$ atau sama dengan nilai VIF $\geq 10$ (Ghozali, 2013:105-106). Apabila nilai tolerance lebih besar sama dengan 0.10 (tolerance $\geq 0.10$ ) atau nilai VIF lebih kecil sama dengan 10 (VIF $\leq 10)$ maka tidak terdapat multikolinieritas dalam penelitian. Hasil uji multikolinieritas dapat dilihat pada Tabel 2 sebagai berikut.

Tabel 2

Hasil Uji Multikolinieritas

\begin{tabular}{|c|c|c|c|}
\hline Variabel & Tolerance & VIF & Kesimpulan \\
\hline CAR & 0,747 & 1,339 & $\begin{array}{l}\text { Tidak terdapat } \\
\text { multikolinieritas }\end{array}$ \\
\hline FDR & 0,920 & 1,087 & $\begin{array}{l}\text { Tidak terdapat } \\
\text { multikolinieritas }\end{array}$ \\
\hline NPF & 0,597 & 1,676 & $\begin{array}{l}\text { Tidak terdapat } \\
\text { multikolinieritas }\end{array}$ \\
\hline $\begin{array}{c}\text { Pertumbuhan } \\
\text { DPK }\end{array}$ & 0,704 & 1,421 & $\begin{array}{l}\text { Tidak terdapat } \\
\text { multikolinieritas }\end{array}$ \\
\hline
\end{tabular}

Sumber: Hasil Uji SPSS 16

3. Uji Heteroskedastisitas

Deteksi ada tidaknya heteroskedastisitas dapat dilakukan dengan melihat grafik plot atau scatterplot antara nilai prediksi variabel dependen yaitu ZPRED dengan residualnya SRESID. Hasil pengujian heteroskedastisitas dapat dilihat pada Gambar 4 berikut.

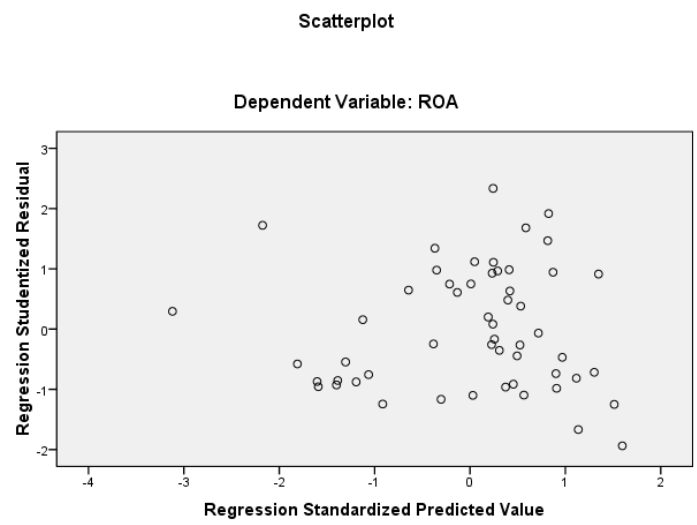

Sumber: Hasil Uji SPSS 16

Gambar 4

Hasil Uji Heteroskedastisitas

Terlihat pada Gambar 4 bahwa pola dalam grafik scatterplot menyebar di atas 
Wulandari, et al/Jurnal Ekonomi Syariah Teori dan Terapan Vol. 4 No. 9 September 2017: 741-756; ANALISIS PENGARUH CAR, FDR, NPF, DAN PERTUMBUHAN DPK TERHADAP PROFITABILITAS PADA INDUSTRI BANK PEMBIAYAAN RAKYAT SYARIAH DI INDONESIA TAHUN 2011-2015

dan di bawah angka 0 pada sumbu $Y$, sehingga tidak terjadi heteroskedastisitas dalam model regresi yang digunakan dalam penelitian ini.

4. Uji Autokorelasi

Hubungan antar variabel dalam penelitian yang menggunakan teknik analisis regresi linier berganda harus terbebas dari masalah autokorelasi. Uji autokorelasi salah satunya dapat menggunakan metode uji Durbin Watson. Apabila angka D-W di antara -2 sampai +2 , berarti tidak ada autokorelasi (Santoso, 2000:219).

Tabel 3

Hasil Uji Autokorelasi Durbin-Watson

\begin{tabular}{|c|c|c|}
\hline $\begin{array}{c}\text { Nilai Durbin- } \\
\text { Watson }\end{array}$ & $\begin{array}{c}\text { Interpretasi } \\
\text { Hasil }\end{array}$ & Keterangan \\
\hline 0,921 & $-2<\mathrm{D}-\mathrm{W}<+2$ & $\begin{array}{c}\text { Tidak terjadi } \\
\text { autokorelasi }\end{array}$ \\
\hline
\end{tabular}

Sumber: Hasil Uji SPSS 16

\section{Analisis Koefisien Determinasi dan Pengujian Hipotesis}

Hasil uji koefisien determinasi dapat dilihat pada Tabel 4 berikut:

Tabel 4

Hasil Uji Koefisien Determinasi

\begin{tabular}{|c|r|r|r|}
\hline$R$ & $\begin{array}{c}R \\
\text { square }\end{array}$ & $\begin{array}{c}\text { Adjusted } \\
\text { R Square }\end{array}$ & $\begin{array}{c}\text { Std. Error of } \\
\text { the Estimate }\end{array}$ \\
\hline $.762^{a}$ & .580 & .546 & .17657 \\
\hline
\end{tabular}

Sumber: Hasil Uji SPSS 16

Berdasarkan Tabel 4 dapat dilihat bahwa hasil uji nilai $\mathrm{R}^{2}$ sebesar 0,58 atau $58 \%$, dengan kata lain 58\% ROA dipengaruhi oleh variabel CAR, FDR, NPF, dan pertumbuhan DPK, sedangkan sisanya sebesar $42 \%$ dipengaruhi oleh faktor-faktor lain diluar model penelitian.
Pengujian hipotesis dilakukan dengan menggunakan dua teknik uji, yaitu uji $F$ dan uji t.

Tabel 5

Hasil Uji F

\begin{tabular}{|l|c|c|}
\hline Signifikansi & Interpretasi & Keterangan \\
\hline 0,000 & $\begin{array}{l}\text { Signifikansi }<\alpha \\
(0,000<0,05)\end{array}$ & Ho ditolak \\
\hline
\end{tabular}

Sumber: Hasil Uji SPSS 16

Berdasarkan Tabel 5 terlihat bahwa signifikansi uji $F$ sebesar 0,000 dimana nilai ini lebih kecil dari a $(0,000<0,05)$, sehingga $\mathrm{H}_{0}$ ditolak. Berdasarkan hasil pengolahan data dapat disimpulkan bahwa CAR, FDR, NPF, dan pertumbuhan DPK secara simultan berpengaruh signifikan terhadap ROA pada BPRS di Indonesia.

Tabel 6

Hasil Uji $\dagger$

\begin{tabular}{|l|c|c|}
\hline \multicolumn{1}{|c|}{ Variabel } & Sig. & Keterangan \\
\hline CAR & 0,426 & $\mathrm{H}_{0}$ diterima \\
\hline FDR & 0,008 & $\mathrm{H}_{0}$ ditolak \\
\hline NPF & 0,000 & $\mathrm{H}_{0}$ ditolak \\
\hline $\begin{array}{l}\text { Pertumbuhan } \\
\text { DPK }\end{array}$ & 0,003 & $\mathrm{H}_{0}$ ditolak \\
\hline
\end{tabular}

Sumber: Hasil Uji SPSS 16

Berdasarkan hasil uji $\uparrow$ pada Tabel 6 dapat dilihat pengaruh masing-masing variabel secara parsial. Apabila nilai signifikansi lebih besar dari $\alpha(0,05)$, maka $\mathrm{H}_{0}$ diterima. Nilai CAR lebih besar dari a yaitu sebesar 0,426 sehingga $\mathrm{H}_{0}$ diterima, sedangkan FDR, NPF, dan Pertumbuhan DPK memiliki nilai lebih kecil dari $\alpha$ sehingga $\mathrm{H}_{0}$ ditolak. Berdasarkan hasil tersebut dapat disimpulkan bahwa secara parsial CAR berpengaruh tidak signifikan terhadap ROA, sedangkan FDR, NPF, dan Pertumbuhan DPK secara parsial berpengaruh signifikan terhadap ROA. 
Wulandari, et al/Jurnal Ekonomi Syariah Teori dan Terapan Vol. 4 No. 9 September 2017: 741-756; ANALISIS PENGARUH CAR, FDR, NPF, DAN PERTUMBUHAN DPK TERHADAP PROFITABILITAS PADA INDUSTRI BANK PEMBIAYAAN RAKYAT SYARIAH DI INDONESIA TAHUN 2011-2015

Pembahasan

Pengaruh CAR, FDR, NPF, dan Pertumbuhan DPK Secara Simultan Terhadap ROA pada BPRS di Indonesia

Hasil penelitian tentang pengaruh CAR, FDR, NPF, dan pertumbuhan DPK terhadap ROA secara simultan menunjukkan nilai signifikansi pada uji $F$ yaitu lebih kecil dari a $(0,000<0,05)$. Berdasarkan hasil uji $\mathrm{F}$ dapat disimpulkan bahwa $\mathrm{H}_{0}$ ditolak, sehingga CAR, FDR, NPF, dan pertumbuhan DPK secara simultan berpengaruh signifikan terhadap ROA. Hal ini menunjukkan bahwa setiap BPRS harus lebih memperhatikan dan meningkatkan kinerjanya sebaik mungkin agar dapat menghasilkan keuntungan yang optimal bagi bank.

ROA merupakan salah satu indikator utama yang digunakan oleh perbankan dalam mengukur kinerja keuangannya. Kasmir (2008:199) menjelaskan bahwa ROA menunjukkan hasil (return) atas jumlah aktiva yang digunakan dalam perusahaan. Semakin tinggi perolehan ROA maka menunjukkan semakin baik kinerja BPRS. Hal ini disebabkan oleh semakin tingginya tingkat keuntungan yang diperoleh bank. Semakin baik manajemen bank dalam menghasilkan keuntungan, maka akan menunjukkan keberhasilan bank dalam menjalankan kegiatannya.

\section{Pengaruh CAR Terhadap ROA pada BPRS di Indonesia}

Berdasarkan hasil pengolahan data uji † diketahui bahwa signifikansi pada CAR sebesar 0,426 dimana nilai ini lebih besar dari a $(0,426>0,05)$, sehingga $\mathrm{H}_{0}$ diterima. Hal ini menunjukkan bahwa CAR secara parsial berpengaruh tidak signifikan terhadap ROA.

CAR digunakan untuk mengukur sejauh mana bank dapat mengelola modal yang dimiliki untuk menyerap kerugian yang dialami perbankan. Dendawijaya (2009:121) juga menjelaskan bahwa CAR merupakan indikator terhadap kemampuan bank untuk menutupi penurunan aktivanya sebagai akibat dari kerugian-kerugian bank yang disebabkan oleh aktiva yang berisiko. Hasil pengolahan data dalam penelitian ini menunjukkan bahwa CAR berpengaruh tidak signifikan terhadap ROA. Hal ini dapat disebabkan oleh kinerja BPRS dalam mengelola kecukupan modal yang dimiliki kurang optimal, sehingga CAR tidak dapat menyerap kerugian yang dialami dengan baik. Wibowo dan Syaichu (2013) mengatakan bahwa bank yang memiliki modal besar namun tidak dapat menggunakan modalnya secara efektif dalam menghasilkan laba, maka tidak akan berpengaruh terhadap profitabilitas. Hasil penelitian ini sesuai dengan penelitian yang dilakukan oleh Widyaningrum dan Septiarini (2015) yang menyatakan bahwa CAR berpengaruh tidak signifikan terhadap ROA pada BPRS di Indonesia.

\section{Pengaruh FDR Terhadap ROA pada BPRS di Indonesia \\ Berdasarkan hasil pengolahan data uji † diketahui bahwa signifikansi pada FDR sebesar 0,008 dimana nilai ini lebih kecil}


Wulandari, et al/Jurnal Ekonomi Syariah Teori dan Terapan Vol. 4 No. 9 September 2017: 741-756; ANALISIS PENGARUH CAR, FDR, NPF, DAN PERTUMBUHAN DPK TERHADAP PROFITABILITAS PADA INDUSTRI BANK PEMBIAYAAN RAKYAT SYARIAH DI INDONESIA TAHUN 2011-2015

dari a $(0,008<0,05)$, sehingga $\mathrm{H}_{0}$ ditolak. Hal ini menunjukkan bahwa FDR secara parsial berpengaruh signifikan terhadap ROA.

FDR menunjukkan kemampuan bank dalam menyediakan dana dan menyalurkan dana kepada masyarakat. Hartono (2007:10) menjelaskan bahwa FDR merupakan karakteristik perbankan syariah dalam memaksimalkan pendapatan, yang dilaksanakan dengan meningkatkan pembiayaan seiring dengan meningkatnya jumlah DPK yang diperoleh. Hasil pengolahan data dalam penelitian ini menunjukkan bahwa FDR berpengaruh signifikan terhadap ROA. Hal ini menunjukkan bahwa BPRS dapat menjalankan kinerjanya sebagai lembaga intermediasi dengan baik. BPRS dinilai dapat menyalurkan pembiayaan kepada masyarakat secara optimal sehingga deposan mempercayakan BPRS dapat mengelola dana yang mereka miliki. Semakin tinggi tingkat kepercayaan masyarakat terhadap BPRS maka akan semakin banyak perolehan dana yang didapatkan dari deposan. Perolehan dana ini dapat mempengaruhi tingkat ROA pada BPRS. Hasil penelitian ini mendukung penelitian yang dilakukan oleh Riyadi dan Yulianto (2014) yang menyatakan bahwa FDR berpengaruh signifikan terhadap ROA pada bank umum syariah.

\section{Pengaruh NPF Terhadap ROA pada BPRS di Indonesia}

Berdasarkan hasil pengolahan data uji † diketahui bahwa signifikansi pada NPF sebesar 0,000 dimana nilai ini lebih kecil dari a $(0,000<0,05)$, sehingga $\mathrm{H}_{0}$ ditolak. Hal ini menunjukkan bahwa NPF secara parsial berpengaruh signifikan terhadap ROA.

NPF merupakan salah satu rasio yang digunakan untuk mengukur tingkat risiko pembiayaan pada BPRS. Risiko pembiayaan terjadi akibat ketidakmampuan nasabah dalam mengembalikan pinjaman yang telah diberikan oleh bank sesuai dengan jangka waktu yang telah disepakati. Berdasarkan Surat Edaran Bank Indonesia Nomor 9/29/DPbS tanggal 7 Desember 2007 dijelaskan bahwa NPF bertujuan untuk mengukur tingkat permasalahan pembiayaan yang dihadapi oleh bank syariah. Hasil pengolahan data dalam penelitian ini menunjukkan bahwa NPF berpengaruh signifikan terhadap ROA. Semakin tinggi NPF menunjukkan semakin tinggi risiko yang dihadapi oleh bank, sebaliknya semakin rendah NPF maka menunjukkan BPRS dapat mengelola pembiayaan dengan baik sehingga hal ini dapat mengurangi risiko bank dan berdampak pada tingkat profitabilitas. Hasil penelitian ini sesuai dengan penelitian yang dilakukan oleh Anastasia dan Septiarini (2015) yang menyatakan bahwa NPF berpengaruh signifikan terhadap ROA.

\section{Pengaruh Pertumbuhan DPK Terhadap ROA pada BPRS di Indonesia}

Berdasarkan hasil pengolahan data uji † diketahui bahwa signifikansi pada pertumbuhan DPK sebesar 0,003 dimana 
Wulandari, et al/Jurnal Ekonomi Syariah Teori dan Terapan Vol. 4 No. 9 September 2017: 741-756; ANALISIS PENGARUH CAR, FDR, NPF, DAN PERTUMBUHAN DPK TERHADAP PROFITABILITAS PADA INDUSTRI BANK PEMBIAYAAN RAKYAT SYARIAH DI INDONESIA TAHUN 2011-2015

nilai ini lebih kecil dari a $(0,003<0,05)$, sehingga $\mathrm{H}_{0}$ ditolak. Hal ini menunjukkan bahwa pertumbuhan DPK secara parsial berpengaruh signifikan terhadap ROA.

Pertumbuhan DPK merupakan salah satu rasio yang digunakan untuk mengukur kinerja BPRS. Dendawijaya (2009:49) menyatakan bahwa bank harus selalu berada di tengah masyarakat agar arus vang dari masyarakat yang kelebihan dana dapat ditampung dan disalurkan kembali kepada masyarakat. Semakin tinggi pertumbuhan DPK yang diperoleh bank menunjukkan semakin tinggi tingkat kepercayaan masyarakat terhadap bank. Peningkatan DPK ini dapat mempengaruhi tingkat profitabilitas BPRS apabila bank dapat melaksanakan kegiatan operasionalnya dengan baik. Hasil pengolahan data dalam penelitian ini menunjukkan bahwa pertumbuhan DPK berpengaruh signifikan terhadap ROA. Hal ini menunjukkan bahwa BPRS mendapatkan kepercayaan dari masyarakat mampu mengelola dana yang diberikan dengan baik. Semakin tinggi perolehan dana pihak ketiga maka akan meningkatkan pembiayaan yang diberikan kepada masyarakat. Tingginya pembiayaan yang diberikan kepada masyarakat ini yang akan mempengaruhi tingkat profitabilitas pada BPRS. Hasil penelitian ini sesuai dengan penelitian yang dilakukan oleh Irianti (2013) yang menyatakan bahwa dana pihak ketiga (DPK) berpengaruh signifikan terhadap ROA perusahaan perbankan.

\section{SIMPULAN}

\section{Simpulan}

Berdasarkan hasil penelitian dan pembahasan yang telah dijelaskan sebelumnya, maka kesimpulan yang dapat diambil dalam penelitian ini adalah sebagai berikut:

1. Berdasarkan hasil statistik uji $F$, menunjukkan bahwa nilai signifikansi lebih kecil dari $\alpha(0,000<0,05)$, sehingga dapat disimpulkan bahwa CAR, FDR, NPF, dan pertumbuhan DPK secara simultan berpengaruh signifikan terhadap ROA pada BPRS di Indonesia tahun 2011-2015.

2. Berdasarkan hasil statistik uji t, menunjukkan bahwa nilai signifikansi CAR lebih besar dari a $(0,426>0,05)$, sehingga dapat disimpulkan bahwa CAR secara parsial berpengaruh tidak signifikan terhadap ROA pada BPRS di Indonesia tahun 2011-2015.

3. Berdasarkan hasil statistik uji t, menunjukkan bahwa nilai signifikansi FDR lebih kecil dari a $(0,008<0,05)$, sehingga dapat disimpulkan bahwa FDR secara parsial berpengaruh signifikan terhadap ROA pada BPRS di Indonesia tahun 2011-2015.

4. Berdasarkan hasil statistik uji t, menunjukkan bahwa nilai signifikansi NPF lebih kecil dari a $(0,000<0,05)$, sehingga dapat disimpulkan bahwa NPF secara parsial berpengaruh signifikan terhadap ROA pada BPRS di Indonesia tahun 2011-2015.

5. Berdasarkan hasil statistik uji $t$, menunjukkan bahwa nilai signifikansi 
Wulandari, et al/Jurnal Ekonomi Syariah Teori dan Terapan Vol. 4 No. 9 September 2017: 741-756; ANALISIS PENGARUH CAR, FDR, NPF, DAN PERTUMBUHAN DPK TERHADAP PROFITABILITAS PADA INDUSTRI BANK PEMBIAYAAN RAKYAT SYARIAH DI INDONESIA TAHUN 2011-2015

pertumbuhan DPK lebih kecil dari $\alpha$ $(0,003<0,05)$, sehingga dapat disimpulkan bahwa pertumbuhan DPK secara parsial berpengaruh signifikan terhadap ROA pada BPRS di Indonesia tahun 2011-2015.

Berdasarkan simpulan yang telah disebutkan sebelumnya, maka saran yang dapat diberikan adalah BPRS diharapkan dapat meningkatkan kinerjanya terutama kinerja keuangannya. BPRS diharapkan dapat menjalankan kegiatannya lebih optimal sebagai lembaga intermediasi, diantaranya memantau kinerja rasio FDR, NPF, dan pertumbuhan DPK, sebab rasiorasio ini memiliki pengaruh yang signifikan terhadap ROA. Meningkatnya peranan BPRS dalam mengelola dan menyalurkan dana kepada masyarakat dapat mempengaruhi tingkat keuntungan (ROA). Mengurangi dan menghindari terjadinya tingkat risiko pembiayaan juga dapat berpengaruh dalam peningkatan profitabilitas. Rasio keuangan lainnya yang juga perlu diperhatikan oleh BPRS adalah rasio CAR, sebab rasio ini sangat penting dimana CAR menunjukkan sejauh mana modal yang dimiliki dapat menyerap kerugian sehingga dapat meningkatkan ROA.

\section{DAFTAR PUSTAKA}

Anastasia, Febby Karina dan Dina Fitrisia Septiarini. 2015. Pengaruh Equity to Total Assets Ratio, Non Performing Ratio dan Financing to Deposit Ratio Terhadap Kinerja Keuangan Koperasi
BMT Nurul Jannah Gresik Tahun 20122014. JEST, 2 (10): 812-827.

Anshori, Muslich dan Sri Iswati. 2009. Buku Ajar Metodologi Penelitian Kuantitatif. Surabaya: Airlangga University Press.

Arifin, Zainul. 2009. Dasar-dasar Manajemen Bank Syariah, edisi revisi. Jakarta: Azkia Publisher.

Dendawijaya, Lukman. 2009. Manajemen Perbankan. Jakarta: Ghalia Indonesia.

Faisol, Ahmad. 2007. Analisis Kinerja Keuangan Bank pada Bank Muamalat Indonesia Tbk, (Online), $\begin{array}{llll}\text { Vol. } & 3 & \text { No. }\end{array}$ (http://www.academia.edu, diakses pada 12 Maret 2016).

Ghozali, Imam. 2013. Aplikasi Analisis Multivariate dengan Program IBM SPSS 21 Update PLS Regresi. Semarang: Badan Penerbit Universitas Diponegoro. Hartono. 2007. Pengaruh Dana Pihak Ketiga dan Suku Bunga Sertifikat Bank Indonesia Terhadap Non Performing Financing Pada Bank Muamalat Indonesia. Jakarta: Tesis S-2 Ekonomi dan Keuangan Syariah Program Studi Timur Tengah dan Islam Program Pascasarjana Universitas Indonesia.

Hermawan, Asep. 2005. Penelitian Bisnis Paradigma Kuantitatif. Jakarta: Grasindo.

Irianti, Tjiptowati Endang. 2013. Pengaruh Rasio Kecukupan Modal, Likuiditas, dan Total Dana Pihak Ketiga Terhadap Tingkat Profitabilitas Perusahaan Perbankan, (Online) Vol. 
Wulandari, et al/Jurnal Ekonomi Syariah Teori dan Terapan Vol. 4 No. 9 September 2017: 741-756; ANALISIS PENGARUH CAR, FDR, NPF, DAN PERTUMBUHAN DPK TERHADAP PROFITABILITAS PADA INDUSTRI BANK PEMBIAYAAN RAKYAT SYARIAH DI INDONESIA TAHUN 2011-2015

24 No. 1, (jurnal.undaris.ac.id, diakses pada 4 September 2016).

Ismail. 2011. Manajemen Perbankan Dari Teori Menuju Aplikasi. Jakarta: Kencana.

Kasmir. 2008. Analisis Laporan Keuangan. Jakarta: PT Raja Grafindo Persada.

Kuncoro, Mudrajad. 2002. Manajemen Perbankan: Teori dan Aplikasi. Yogyakarta: BPFE.

Nirwana, Lutfiyah Putri dan Dina Fitrisia Septiarini. 2015. Pengaruh Pertumbuhan Dana Pihak Ketiga terhadap Laba Perbankan Syariah di Indonesia. JEST, 2 (8): 642-657.

Prasetyoningrum, Ari Kristin. 2010. Analisis Pengaruh Independensi dan Profesionalisme Dewan Pengawas Syariah terhadap Kinerja Bank Perkreditan Rakyat Syariah di Jawa Tengah, (Online), Vol. 12 No. 1, (http://www.jurnal.widyamanggala.ac.i d, diakses pada 3 Juni 2016).

Republik Indonesia. Surat Edaran Bank Syariah Nomor 9/29/DPbs/2007 Tentang Sistem Penilaian Tingkat Kesehatan Bank Pengkreditan Rakyat Berdasarkan Prinsip Syariah. Jakarta: Bank Indonesia. Riyadi, Slamet dan Agung Yulianto. 2014. Pengaruh Pembiayaan Bagian Hasil, Pembiayaan Jual Beli, Financing to Deposit Ratio (FDR) dan Non Performing Financing (NPF)Terhadap Profitabilitas Bank Umum Syariah di Indonesia, (Online), Vol. 3 No. 4, (http://journal.unnes.ac.id, diakses pada 12 April 2016).
Santoso, Singgih. 2000. BukU Latihan SPSS:

Statistik Parametrik. Elex Media Komputindo.

Sholihin, Ahmad Ifham. 2010. Buku Pintar Ekonomi Syariah. Jakarta: Gramedia Pustaka Utama.

Statistik Perbankan Syariah, Bank Indonesia.

Sudarsono, Heri. 2007. Bank dan Lembaga Kevangan Syariah. Yogyakarta: Ekonisia.

Sujarweni, V. Wiratma. 2014. SPSS untuk Penelitian. Yogyakarta: Pustaka Baru Press.

Sukarno, Kartika Wahyu dan Muhammad Syaichu. 2006. Analisis Faktor-faktor yang Mempengaruhi Kinerja Bank Umum di Indonesia, (Online), Vol. 3 No. 2, (http://ejournal.undip.ac.id, diakses pada 2 Maret 2016).

Wangsawidjaja Z, A. 2012. Pembiayaan Bank Syariah. Jakarta: PT Gramedia Pustaka Utama.

Wibowo, Edhi Satriyo dan Muhammad Syaichu. 2013. Analisis Pengaruh Suku Bunga, Inflasi, CAR, BOPO, NPF terhadap Profitabilitas Bank Syariah. Diponegoro Journal of Accounting, 2 (2): 1-10.

Widyaningrum, Linda dan Dina Fitrisia Septiarini. 2015. Pengaruh CAR, NPF, FDR, dan OER terhadap ROA pada Bank Pembiayaan Rakyat Syariah di Indonesia Periode Januari 2009 hingga Mei 2014. JEST, 2 (12): $970-$ 985. 